\title{
Notes on the vocalizations of Masked Gnatcatcher (Polioptila dumicola)
}

Peter Boesman

In the following we briefly analyze and compare voice of the three races of Masked Gnatcatcher (Polioptila dumicola). We also try to quantify the extent of any vocal differences using the criteria proposed by Tobias et al. (2010), as a support for taxonomic review. We have made use of sound recordings available on-line from Xeno Canto (XC).

\section{Races dumicola and saturata}

Song is typically a series of notes, including at least in part a repetition of about the same notes or note pairs, at about constant pitch.

Some examples:

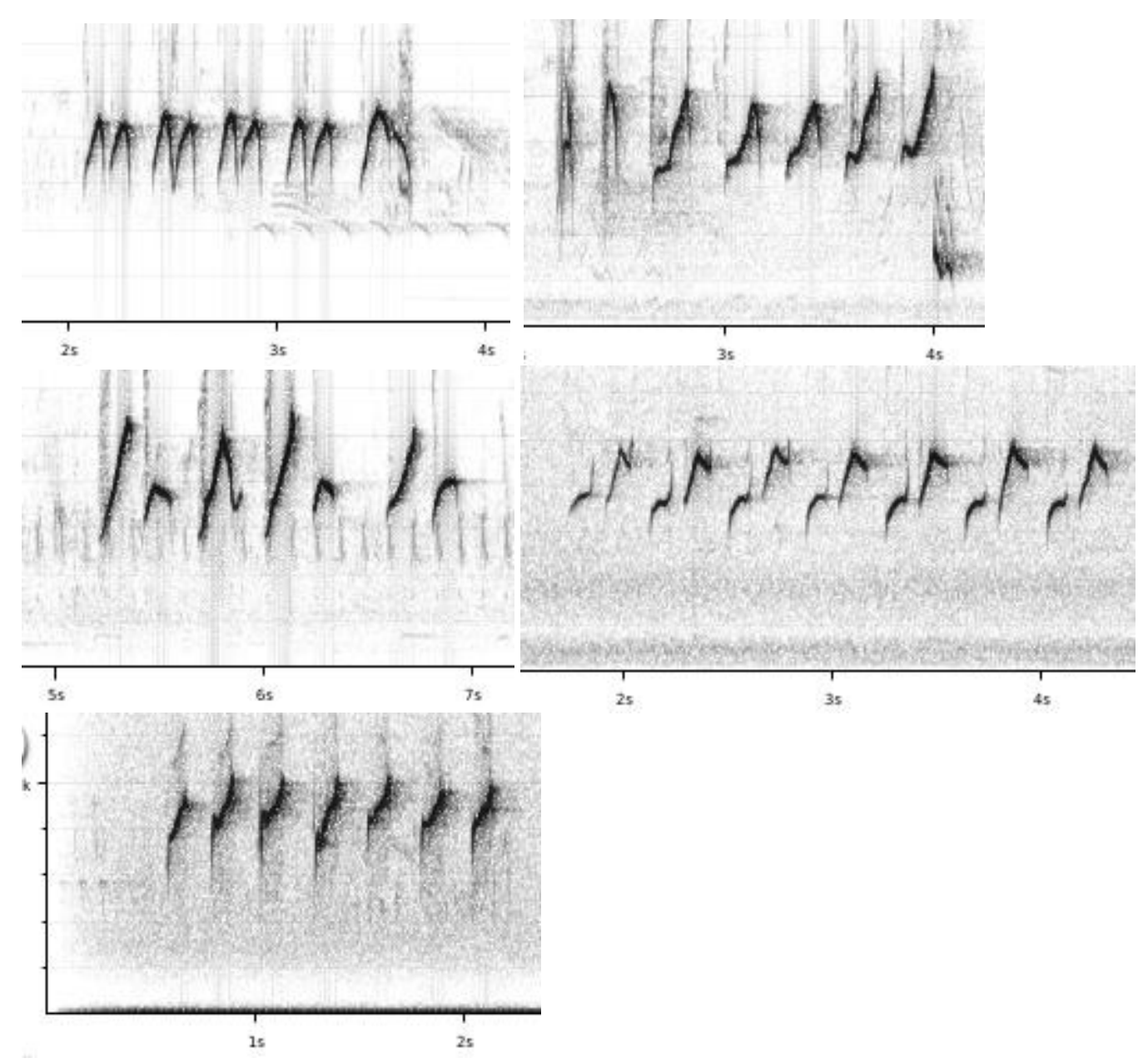




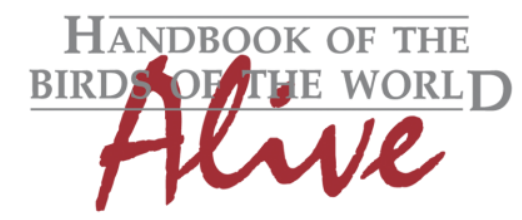

\section{ORNITHOLOGICAL NOTES}

\section{Race berlepschi}

Song is quite variable, typically a note series which rises or falls in pitch. Notes are similarshaped, but are not necessarily exact repeats.

Some examples:
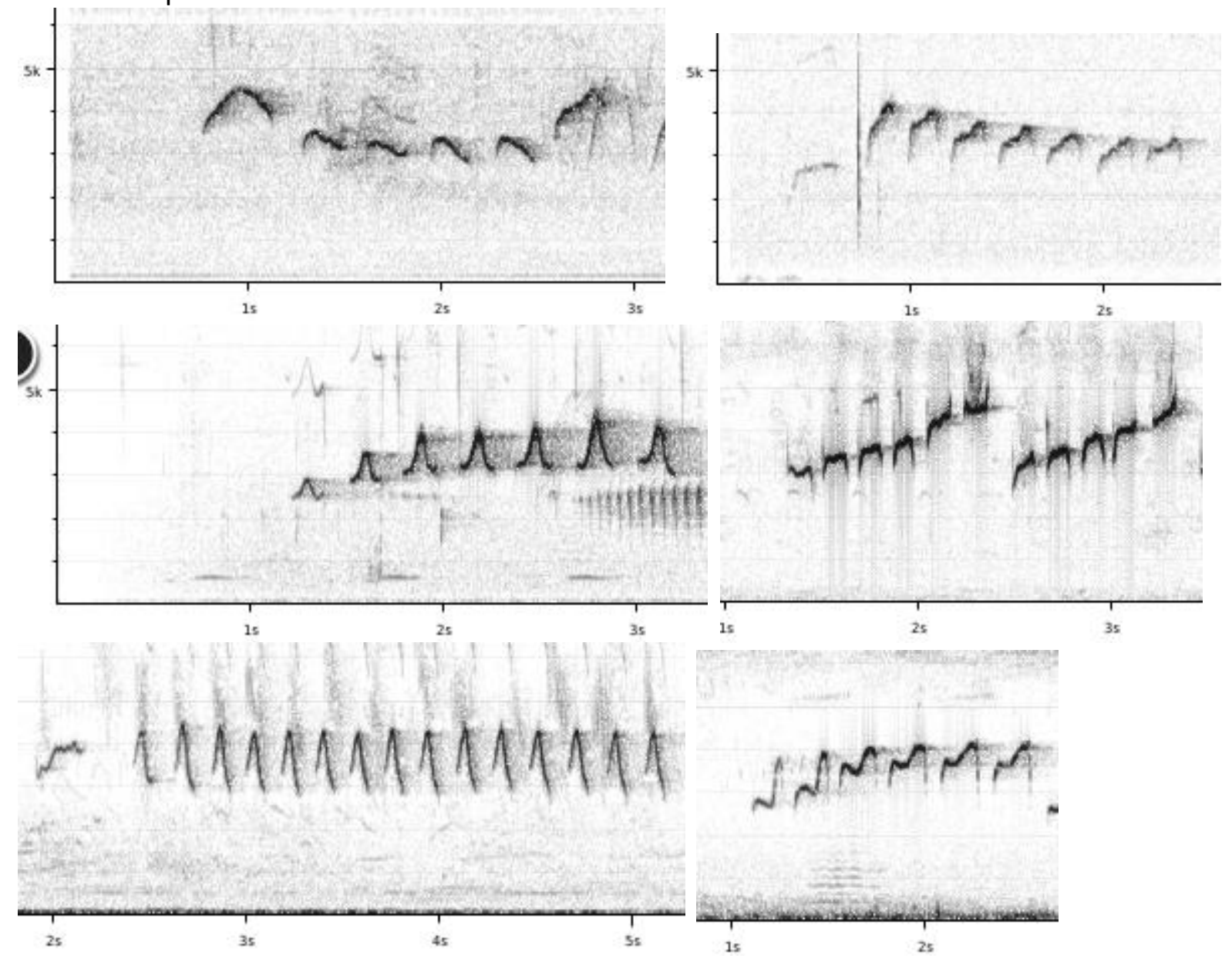

There is a high variability in song of both groups.

On average, berlepschi seems to have notes (or repeated note pairs) which cover a narrower frequency range, and the song phrase more often has a rising or falling pitch.

There is however clearly overlap, and a more in depth statistical analysis would be needed to quantify more precisely differences in vocal parameters.

Based on the average differences mentioned above, we estimate the total vocal score to be about $1+1=2$.

This note was finalized on 14th April 2016, using sound recordings available on-line at that moment. We would like to thank in particular the many sound recordists who placed their recordings for this species on XC. 


\section{References}

Tobias, J.A., Seddon, N., Spottiswoode, C.N., Pilgrim, J.D., Fishpool, L.D.C. \& Collar, N.J. (2010). Quantitative criteria for species delimitation. Ibis 152(4): 724-746.

\section{Recommended citation}

Boesman, P. (2016). Notes on the vocalizations of Masked Gnatcatcher (Polioptila dumicola). HBW Alive Ornithological Note 281. In: Handbook of the Birds of the World Alive. Lynx Edicions, Barcelona. (retrieved from http://www.hbw.com/node/1251722 on 11 October 2016). 